\title{
THE REPRESENTATION OF BEAUTY IN PANTENE SHAMPOO ADVERTISEMENT
}

\author{
Mahdalena \\ Dedi Sulaeman \\ Pepen Priyawan \\ State Islamic University Sunan Gunung Djati Bandung
}

\begin{abstract}
Advertisement is a persuasive media aimed to persuading and influencing the public. Every day, advertisement can be found anywhere, such as in newspaper, television, radio, and also magazine. Pantene is a shampoo product that is very famous especially among women. Its advertisement can be found almost in every media. In this research, the researcher focuses on the semiotics elements found on Pantene advertisement using Charles Sanders Pierce's theory. The problem in this research then formulated into three questions: (1) How is the process symbol of shampoo advertisement in each text of tagline (2) How is the process of triadic relation in each picture on shampoo advertisement. (3) How are the relation between the text and its picture on every shampoo advertisement. This research used Peirce theory of semiotic to analyze Pantene advertisement. Based on Pierce theory of semiotics, there are representament, object and interpretant. This research uses qualitative method because the data consist of words and pictures. The data of this research are taken from online media. After collecting the data, the researcher analyzes the data about how is the process symbol of shampoo advertisement in each text of tagline, how is the process of triadic relation in each picture on shampoo advertisement, and how are the relation between the text and its picture on every shampoo advertisement using Pierce's theory. The result of this research shows that both the symbol and also the picture on the Pantene's advertisement have representament, object, and interpretant. The representament is something that enters into relation with its object, the second component of the sign, the object is something beyond the sign to which it refers, and interpretant is a concept of thinking from the people who use a sign and give it special meaning which is referred by the sign. By using many different of pictures on the advertisement, it will make people easier to understand and make them more interested to the product.
\end{abstract}

Key words: Semiotic, Triadic Relation, Advertisement, Shampoo, Beauty.

\section{Introduction}

Nowadays, modern people not only use language as communication media, but also people use the technology such as electronic message, television, radio, newspaper, and magazine. People tend to use all of those to deliver their purposes like invitation, persuasion, exclamation, and argumentation. It must be seen in electronic or printed advertisement which is used by advertisement maker to persuade the reader, listener, and audience as a consumer. The advertisement itself is one of the communication media to motivate and persuade collectively in order to attract people on the goods and services which are offered. 
According to Prentice Hall (1990: 185) the term of advertising, is a message which is published or broadcasted in the mass media. It is designed to provide information that will help to persuade people to buy or accept goods, service or ideas. Advertising is paid for by an identifiable sponsor, and it is controlled, its mean, the paying sponsor controls when, where and how the ads appears. The advertising id impersonal, it appeals to broad groups through mass media.

Afterward, the development of advertisement and advertising system in the consumer society altered to the any problem of social and cultural landscape. The problem primarily about the usage of sign, the image that appeared, and the information that told, a meaning, and how the advertising can influence the perception, understanding and people behave. Whether the advertising extends the information about the product offered concretely or, on the contrary, just extends about the falsifying the reality. (Yasraf, Amir. 2003: 280).

In this globalization era, competitions of products are unavoidable by any companies, so they should really keep their existence in the marketing world.one of the important activities to communicate the quality of the product to public is through advertising. Advertising plays a very important role in determining the success in marketing products. The aim is to attract many consumers in order to increase the profit of the company. Putting a good picture and slogan in advertising has purpose to make the consumers could keep the advertising in their mind for a long time, so they would like to use the product. Particular products can appear in our mind, if the advertiser compiles good pictures and slogans. Therefore, the pictures function to emphasize the text in constructing good messages.

The effect of advertising is really fantastic. In a short time, one product will be known and finally used by many people simultaneously. Besides that, the products also may create a new community (product user community), even social class in society. Advertiser should pay attention on the visual messages and verbal messages for the benefits of the product in order to give better understanding to the audience. In creating advertisement, the advertiser should pay attention on signs, symbols, and meaning that can be understood by the local audience because it is related to the background of the audience.

The advertising produced for the audience contained with a certain message. A message created with a many codes aimed to the audience for understanding it. The code appears directed to influence the audience to buy the product advertised, and this is not arbitrary codes, but it is a code with a message inherent within the advertising. In advertisement, language is used as a media of exchanging messages and a communications tool between producers and consumers. Through pictures and words of an advertisement resulted in sign. All of this forms a communication process that has important strengths as a marketing tool in the form of information that is persuasive.

To make interest product well, the producer have to work hard, how to make their product will be sold out by their strategy for product ads. So then, the advertisement sometimes just promote their product to produce the benefit by using the women as attraction and not too show the meaning through the women's image or picture on the first. 
All the signs and symbols appear in the advertising text are representing social realities that exist in society, so the advertising is closely related to the sense of the audience like some of the advertising that used women as the icon of the product that represents the social reality of women. Therefore, the authors choose advertising as the object of research, because every advertisement always fills of signs to promote the product but not all advertisement convey their message directly. The writer does this research to find the deep meaning about slogan and picture in advertising, and see the relationship between advertising and social reality of the audience especially for advertising that use women as the icon of product and its representation of woman in advertisement.

In simple terms, representation can be described as the image of a person or a phenomenon that language use constructs. Naturally, the concept is rarely as simple and language use is not the only tool used to construct representations. The ways we see people similar to ourselves represented in texts and images around us, changes the ways we construct and perform our identities. In fact, Blommaert (2005: 205) emphasizes that people do not have a static identity but rather that identities are constructed through different practices and are constantly changing. Media representations have a strong influence on how we perceive other people but also how we perceive ourselves. As beauty product advertisements are mainly aimed at women and portray women in them, they play an important role in the representation of women in mass media. Thus, beauty advertisements contribute significantly to the ideas of what it is to be a woman.

The researcher is interested in analyzing symbols in shampoo advertisement because the symbol can actually be found in textual word and picture. Besides, the researcher chooses the text from the advertisement taglines because the tagline itself contains a lot of hidden meanings which there are so many symbols in the game. The more interesting thing is the picture and it's tagline of shampoo advertisement can describe the whole meaning just because of the tagline and its picture. Another interesting thing is the picture of the advertisement representate the beautiness of woman from the advertisement itself and the tagline describes how the shampoo works by using unique words.

In the other hand, the image of advertisement has the possibility of differences between the image and the real product's usage or benefits. It demands the consumers to be smarter in seeing or hearing an advertisement. Then in understanding an advertisement, semiotics should be applied because an advertisement contains several signs. Generally, semiotics is a branch of science which is examined a sign or symbol and the procedure of signaling system. Based on the point of view above, it is necessary to have further research about finding out what the true meaning related to the game in each symbols. The form of the paper with will be elaborated in the research entitled: "Symbol on Battle Title of Role-play Games Based on Google Play." 


\section{Disscusion}

The first analysis aims to find out the meaning of symbol in Shampoo Advertisement. The symbol itself formed as text of tagline which contains a hidden meaning. Then the purpose of the second analysis is to find out the meaning about the picture of shampoo advertisement. The last analysis is finding the representation of beauty by combining the two analyzes which discuss the problem between text and pictures. By finding the relation between text and picture, the researcher can reveal the hidden meanings behind the advertisement whether the message from the advertiser is delivered to the reader.

\subsection{Process symbol of shampoo advertisement in each text of tagline}

Having observed all semiotic elements of each shampoo advertisement, in this section the researcher explains and discusses the semiotic triadic in each taglines. The researcher finds the representamen $(\mathrm{R})$, the object $(\mathrm{O})$ and the interpretant (I). In this point the researcher tries to analyze the symbol from the text which used in PANTENE shampoo advertisement as tagline. Thus, the following sections will explain the triadic relation in those signs.

\section{Data}

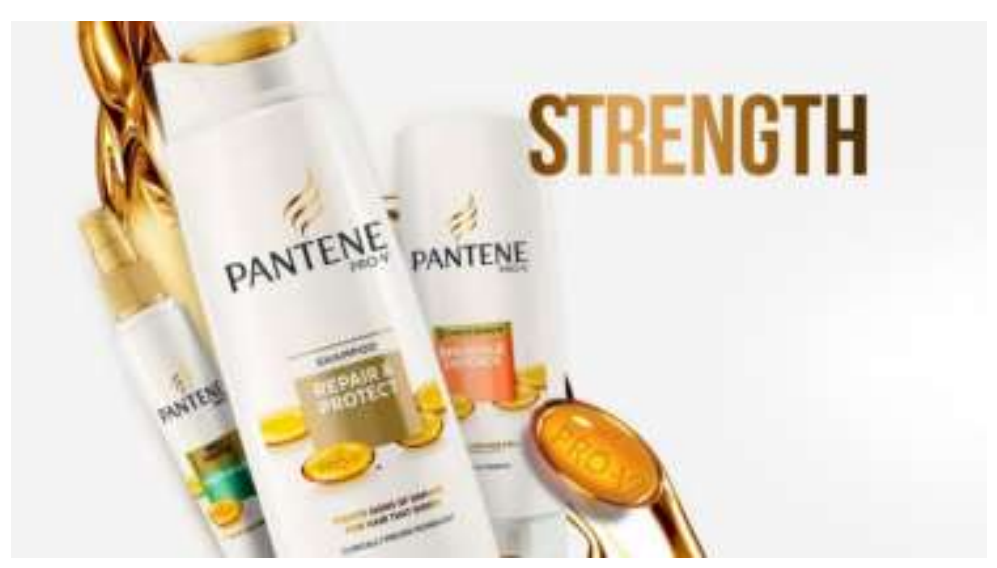

In this data, there is a screenshot image contained information. This screenshot contains written text (symbol) and a picture. The word Stength is the tagline that is representamen as verbal language.

The symbol in this picture is Strength. Strength (noun) is a quality of being physically strong (Hornby, 2008: 1476). From the Pierce's theory of semiotics, the written language of Strength is the representamen (R).

The word Strength is the representamen $(\mathrm{R})$ which personates power, physical and strong refers to object $(\mathrm{O})$. Furthermore, the relationship between the representamen and object produces the interpretant (I) as the third elements. The triadic relation process is: 
(Representamen)

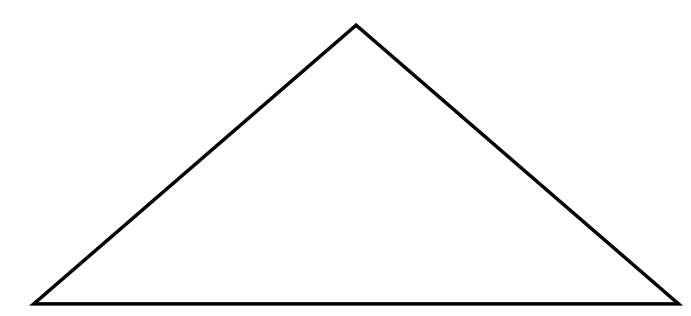

Natural power (Interpretant)

Powers, physical and strong (Object)

a. Representamen $(\mathrm{R})$ is the written text of Strength.

b. Object $(\mathrm{O})$ is personates a power, physical and strong.

c. Interpretant (I) the word of strength basically representation of the power of physical situation. Strength also known in public meaning is connected with a person's body rather than their mind.

\begin{tabular}{|l|l|}
\hline $\begin{array}{l}\text { Representamen to } \\
\text { Representamen }\end{array}$ & $\begin{array}{l}\text { Qualisign: the word Strength here is still have a lot } \\
\text { of potential representation because the } \\
\text { representamen here is still formed by quality and } \\
\text { colors. The word Strength is gives an impression of } \\
\text { something great and also strong when reading them. } \\
\text { Sinsign: the word of Strength in here is personates } \\
\text { power, physical and strong. } \\
\text { Legisign: a physical power which is connected with } \\
\text { a person's body rather than their mind. }\end{array}$ \\
\hline $\begin{array}{l}\text { Object } \\
\text { Representamen }\end{array}$ & $\begin{array}{l}\text { Icon: the word Strength is textual form that comes } \\
\text { from the verbal language. } \\
\text { Index: this happens because there is a causal } \\
\text { relationship between the base and the object. The } \\
\text { word of Strength in here is personates power, } \\
\text { physical and strong. } \\
\text { Symbol: Strength (noun) is a quality of being } \\
\text { physically strong (Hornby, 2008: 1476). }\end{array}$ \\
\hline $\begin{array}{l}\text { Interpretant } \\
\text { Representamen }\end{array}$ & $\begin{array}{l}\text { Rheme: the word Strength here is still have a lot of } \\
\text { potential representation. } \\
\text { Dicisign: Representamen that can be used as real } \\
\text { facts and have certain meanings. The word Strength } \\
\text { came from somebody that has a lot of powers which } \\
\text { be able to defeat each other using physical force. } \\
\text { Argument: this is a sign that contains a reason for } \\
\text { something. The word strength gives the impressions } \\
\text { to the reader that there is somebody which has a lot } \\
\text { of physical power. }\end{array}$ \\
\hline
\end{tabular}

1.2 The process of triadic relation in each picture on shampoo advertisement After finding the symbol of the text in PANTENE shampoo advertisement, the second step is to find out the process of triadic relation in the picture based on C.S Peirce theory. 
Data

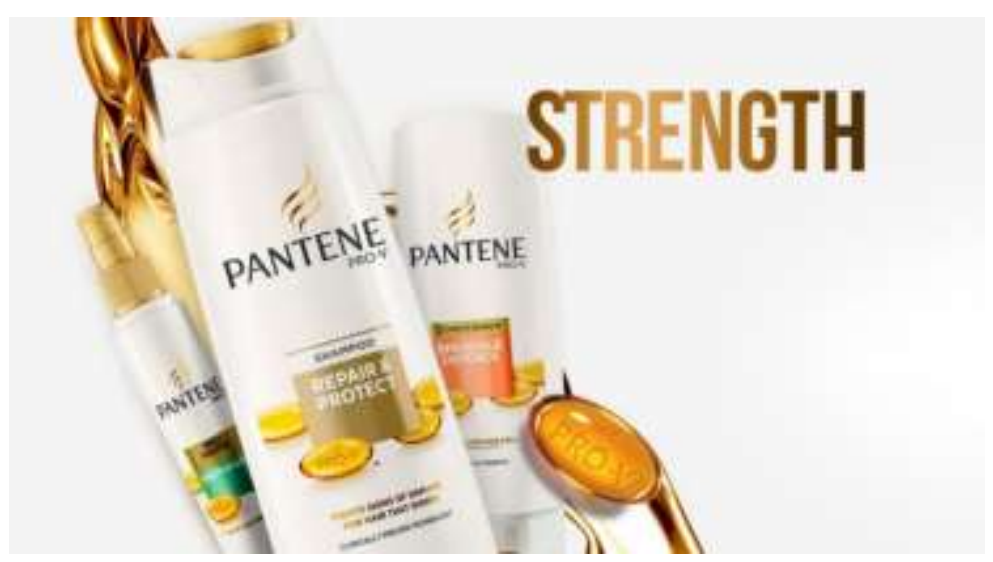

The picture of three bottles of Pantene shampoo, the left is conditioner shampoo. It can be seen from the bottle cap. The middle and the right one is same kind of shampo, and there are a word strength written in capital letter and also something like brown gel written Pro- $\mathrm{V}$, and luxury decoration is a Representamen (R) which personates elegant, beauty, and smooth refers to object (O). Furthermore, the relationship between the representamen and object produces the interpretant (I) as the third elements. The triadic relation process is:

\section{(Representamen)}

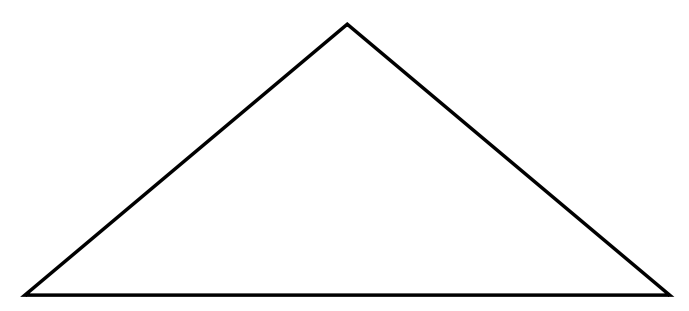
Perfect shampoo
Elegant,
beauty
and
smooth
(Interpretant)
(Object)

a. Representamen $(\mathrm{R})$ is the picture of Pantene Shampoo Advertisement.

b. Object $(\mathrm{O})$ is personates an elegant, beauty, and smooth.

c. Interpretant (I) the picture contains informations about the product itself. People who see the advertisement will know that there are many kinds of product of Pantene shampoo, because the picture shows those three products have different function. The left one is to make the hair smooth and sleek, the middle one is to repair and protect the hair and the right one is for breakage defence. The picture also shows that those products contain Pro- $\mathrm{V}$ that is important element for hair. There is also a word strength written in capital in order to attract the customers that those products can strengthen the hair. The background is white because white is the representation of beautifulness. 


\begin{tabular}{|c|c|}
\hline $\begin{array}{l}\text { Representamen to } \\
\text { Representamen }\end{array}$ & $\begin{array}{l}\text { Qualisign: The picture of three bottles of Pantene } \\
\text { shampoo. } \\
\text { Sinsign: the picture above is one of many Pantene } \\
\text { advertisements which mean the representamen in } \\
\text { sinsign level here is the Pantene company has } \\
\text { many kinds of product of Pantene shampoo, } \\
\text { because the picture shows those three products } \\
\text { have different functions. } \\
\text { Legisign: Pantene company confirmed that the } \\
\text { Pantene has many kinds of product of Pantene } \\
\text { shampoo which already seen at the picture above. }\end{array}$ \\
\hline $\begin{array}{l}\text { Object to } \\
\text { Representamen }\end{array}$ & $\begin{array}{l}\text { Icon: three bottle of the Pantene products and } \\
\text { some luxury decorations. } \\
\text { Index: this happens because there is a causal } \\
\text { relationship between the base and the object. The } \\
\text { design describe that the shampoo personates } \\
\text { elegant, beauty, and smooth. } \\
\text { Symbol: the graphic design of advertisement } \\
\text { picture makes the reader imagines something } \\
\text { elegant will happen if the reader use all of the } \\
\text { products which have been seen at the picture } \\
\text { above. }\end{array}$ \\
\hline $\begin{array}{l}\text { Interpretant to } \\
\text { Representamen }\end{array}$ & $\begin{array}{l}\text { Rheme: the graphic design of three bottles of } \\
\text { Pantene products here is still have a lot of potential } \\
\text { representation. } \\
\text { Dicisign: graphic design from this image shows } \\
\text { that Pantene product is luxury and makes someone } \\
\text { who used it will become beauty. } \\
\text { Argument: this is a sign that contains a reason for } \\
\text { something. The company described directly to the } \\
\text { reader or what the product is look liked. There is } \\
\text { also a word strength written in capital in order to } \\
\text { attract the customers that those products can } \\
\text { strengthen the hair. }\end{array}$ \\
\hline
\end{tabular}

1.3 The relationship between text and it is picture on every shampoo advertisement

After finding the symbol of the text in shampoo advertisement and finding out the process of triadic relation in the picture based on C.S Peirce theory, the last part is to find out the relationship between both of them in order to find the right interpretation about the whole of advertisement. 
Data

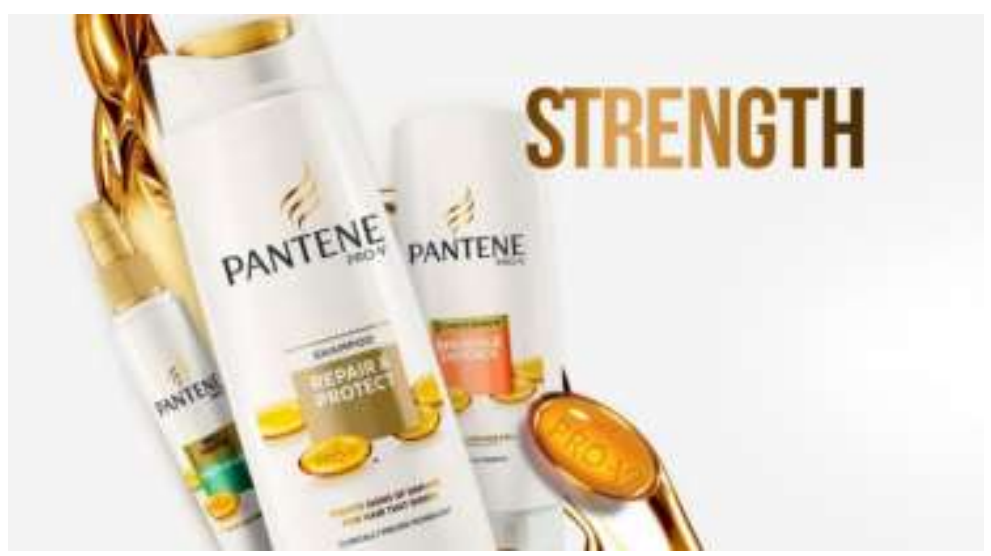

The Pantene's brand design above shows several bottles of Pantene shampoo, a tagline brand and some elegantly decorations. This pictorial product is a contrasting element with the image of a Pantene shampoo product as usual as shown side by side with the tagline that has meaning in order to give an impression to the reader. The design above wants to persuade the customer, especially for women who want to have strength hair. The company tried to attract the costumer by using such an elegant design in order to represent beautifulness. The word strength also written in big font, hopefully those who see the advertisement will understand that all of those product can strengthen their hair.

The last is the conclusion for finding the relationship between picture and text. From what have been seen, this advertisement sends the message to the customer by giving such an elegant design and text in order to give provide an overview of the shampoo directly to the customers.

The representation of beautifulness as personalized in Pantene's design shows that the Pantene has a lot of product to make the reader beauty. The reader would aware that this pictorial product would no meaning if it not relate with the tagline beside the picture. A meaning would appear when this pictorial product has an interpretant about the Pantene's product will make the reader become more beauty after using the product. The pictorial product as represent in several bottle of Pantene product and a linguistic phrases beside its picture supports the idea of interpretation about Pantene shampoo can make someone more beautiful. It also has the impression that the reader who use Pantene product, will have their own satisfaction. In addition, using Pantene product, the reader can feel the hair stronger after a using it and will be refreshed.

The pictorial product of s Pantene has many various with different function. The left one is form make the hair smooth and sleek, the middle is to repair and protect the hair, the the right one is for breakage defence of the hair. It can be seen from the picture that those shampoo is divided into three kinds with different function, the text on the bottle says it all. But, the reader can see that there is a word strength outside the bottle, it means that although those shampoo have different main function, all of them can strengthen the hair. 


\section{Conclusion}

The triadic relation process is started from the representamen. The representamen is the language, written text, picture, or the possible combination of them. The researcher finds some conclusions based on the question of the research:

1. The researcher analyze 15 object from Pantene using triadic relation process for finding the symbol that appear on the tagline. The written text as symbol which have been seen on the pictorial products is the symbol and also the representamen. Then, the triadic relation process is continued to the next step; determining object. The last is interpretant, it is the researcher's exegesis of the combination of the representamen and object. So, the triadic relation process which occurs on the taglines happened in three steps: representamen, object, and interpretant. And these steps are described by Peirce's triadic relation process.

2. The researcher able to find out the meaning about pictorial brand design which has been examined using Pierce triadic relation process. By finding the meaning of picture which makes the reader driven into the imagination and impression of the picture.

3. The researcher finds some conclusions which have been classified after finding the relation between the text and picture. The result of the classification is divided into three directions and clues: the company sending the message to the reader to give to give provide an overview of product, sending message about give an example of the product, and sending message to persuade the reader.

\section{References}

Hall, Prentice (1990). Organizations: Structure and Process. New Jersey: PrenticeHall.

Yasraf Amir Piliang. (2003). Hipersemiotika Tafsir Cultural Studies Atas Matinya Makna. Yogyakarta: Jalasutra.

Blommaert, J. (2005). Discourse: A critical introduction. Cambridge: University Press.

Hornby, A,S. (2008). Oxford Advanced Learner's Dictionary. New York: Oxford University Press. 